DOI: 10.12731/wsd-2017-2-121-141

УДК 612.111: 616.152.21

\title{
ОСОБЕННОСТИ ИЗМЕНЕНИЯ ДИАМЕТРА ЭРИТРОЦИТОВ В КРОВИ СПОРТСМЕНОВ В УСЛОВИЯХ ФИЗИЧЕСКОЙ НАГРУЗКИ
}

\author{
Рубцова Л.Ю., Потолицына Н.Н., Монгалёв Н.П.
}

Цель. Изучить характер распределения эритроцитов по диаметру в ииркулирующей крови льюников-гонщиков в период достижения порога анаэробного обмена (ПАНО).

Материалы и методы. Обследованы лыжники-гонщики (юноши и мужчины, девушки и женщины) в условиях физической нагрузки на велоэргометре в возрасте 17-37 лет $(n=33)$ с квалификацией КМС и МС. Исследование проведено согласно протоколу, утвержденному локальным комитетом по биоэтике при Институте физиологии Коми научного иентра Уральского отделения Российской академии наук. Пробы крови брали из локтевой вень натощак, затем из капилляров пальца до, - на пороге анаэробного обмена, после выполнения нагрузки «до отказа» и через 5 мин восстановления.

На окрашенных мазках крови измеряли диаметр 50 эритроцитов (Лабораторные ..., 1987). Результаты обрабатывали статистически с использованием пакета прикладных программ Windows (Basic, 2011).

Результаты. На этапе ПАНО у $36 \%$ спортсменов определили уве-

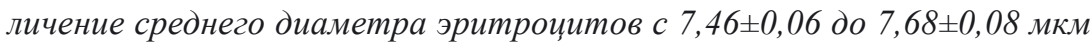
$(p<0,05)$, без изменений у $12 \%(7,45 \pm 0,04-7,43 \pm 0,05$ мкм) и уменьшение

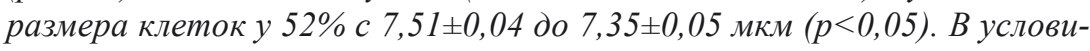

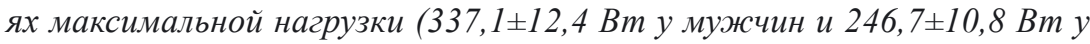
женщин) и на 5-й мин восстановления диаметр эритроцитов в крови спортсменов возвращчался к исходному значению.

Заключение. Таким образом, индивидуальный характер изменения среднего диаметра эритроцитов у спортсменов проявляется во время достижения ПАНО и, вероятно, соответствует избирательной элиминации преимущественно макро- или микроцичтов.

Ключевые слова: диаметр эритроцитов; физическая нагрузка; ПАНО. 


\title{
VALUE CHANGE DIAMETERRED BLOOD CELLS ATHLETES IN THE PHYSICAL LOAD
}

\author{
Rubtsova L.YU., Potolitsyna N.N., Mongalev N.P.
}

Background: to study the nature of distribution of erythrocytes on diameter in the circulating blood of skiers-racers during achievement of a threshold of anaerobic threshold (AT).

Materials and methods: Professional Skiers racers (young men and men, girls and women) at the age of 17-37 years $(n=33)$ are examined in the conditions of physical activity on the stationary bicycle. The research is conducted according to the protocol approved by local committee on bioethics in case of Institute of Physiology of Komi Scientific Centre of the Ural Branch of the Russian Academy of Sciences. Samples of blood were taken from an elbow vein on an empty stomach, then from finger capillaries to, - on a threshold of anaerobic exchange, after execution of loading "to the full" and in 5 min restoration. On the stained blood smears measured diameter of 50 erythrocytes. Results processed statistically with use of an application program package of Windows (Basic, 2011).

Results: At stage AT at $36 \%$ of athletes defined increase in average diameter of erythrocytes from 7,46 $\pm 0,06$ to 7,68 $\pm 0,08 \mu \mathrm{m}(p<0,05)$, without changes at $12 \%(7,45 \pm 0,04-7,43 \pm 0,05 \mu \mathrm{m})$ and reduction of the size of

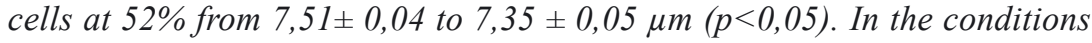
of a maximum load (men have 337,1 $\pm 12,4 \mathrm{~W}$ and women have 246,7 $\pm 10,8$ $W$ ) and during the 5-minute recovery diameter of erythrocytes returned to the original value.

Conclusion: Thus, the individual nature of change of average diameter of erythrocytes at athletes is shown during achievement of ANSPs and probably corresponds to selective elimination preferentially macro- or microcytes.

Keywords: diameter of erythrocytes; physical load; AT.

\section{Введение}

Реакция системы крови на физическую нагрузку предполагает существование поэтапного включения различных механизмов, обеспечивающих адаптацию к повышенному кислородному запросу [1]. Этот сложный процесс адаптации начинается с мобилизации и перераспределения резервов функциональных систем, реагирующих на экстремальную ситуацию $[2,3]$. Физическая нагрузка сопровождается выбросом в циркулирующую 
кровь депонированных эритроцитов $[4,5]$, то есть «более старых», имеющих меньший диаметр, с измененной газотранспортной функцией [6, 7]. Усиление деструкции (гемолиза) эритроцитов в крови, наряду с поступлением ретикулоцитов $[8,9]$, сочетается с их перераспределением и морфологической модификацией [10], функциональная значимость которой еще далеко не изучена. В работе представлен сравнительный морфометрический материал по эритроцитам из венозной и капиллярной крови человека во время физической нагрузки.

Целью исследования было определение значение распределения эритроцитов по диаметру в циркулирующей крови лыжников-гонщиков до и после момента порога анаэробного обмена.

\section{Материалы и методы исследований}

Обследованы практически здоровые лыжники-гонщики в возрасте 17 37 лет (n=33) с квалификацией КМС и МС в весенне-летний период. Юноши и мужчины, девушки и женщины добровольно принимали участие в исследовании влияния физической нагрузки на морфофункциональное и биохимическое состояние крови, согласно протоколу исследования, утвержденному локальным комитетом по биоэтике при Институте физиологии Коми научного центра Уральского отделения Российской академии наук.

У спортсменов утром натощак производили фоновый забор крови из локтевой вены, затем через 1-1,5 часа из капилляров пальца во время теста «до отказа» на эргоспирометрической системе Oxycon Pro (Jaeger, Германия) до порога анаэробного обмена (ПАНО), при достижении ПАНО, в период максимальной нагрузки и на 5-й мин восстановления.

На мазках крови, окрашенных по Романовскому-Гимза (Vital-Development), измеряли диаметр 50 эритроцитов с помощью микроскопа МБ (Poland) с масляной иммерсией, увеличение об. 100 ок. с градуированной шкалой $12^{x}$ [11]. Распределение микро, - до 6,99 мкм, нормо - от 7 до 7,99 мкм и макроцитов от 8 мкм и более по диаметру от наименьшей величины 6 мкм до максимальной 9,5 мкм вели по всей группе лиц с i =0,3 мкм с точностью до второго знака после запятой [12]. Определение гематокрита проводили с помощью центрифуги MPW-310 (Poland).

Результаты обрабатывали статистически с использованием пакета прикладных программ Windows (Basic, 2011). Для сравнения различий применяли t-критерий Стьюдента для малых выборок с уровнем значимости от 0,05 до 0,001 . Результаты представлены в виде среднего арифметического (M), ошибки средней (m). 


\section{Результаты исследований и их обсуждение}

Уровень гематокрита (табл. 1) соответствует известным величинам характерным для спортсменов $[1,13]$ с учетом того, что исследование проведено в весенне-летний период, в течение которого основные показатели красной крови спортсменов снижаются [14]. Различия по величине гематокрита у спортсменов ( $<0,001)$ сохраняются в динамике исследования с той разницей, что у лиц женского пола значимое повышение показателя наблюдали во время педалирования при нагрузке $188,9 \pm 13,8$ Вт, тогда как у лиц мужского пола $-285,7 \pm 11,7$ Вт, совпадающее с зоной ПАНО $(\mathrm{p}<0,01)$.

Изменение величины гематокрита во время физической нагрузки (ФН) зависит от интенсивности потока крови [15] и является характерным признаком включения в циркуляцию депонированной крови [5]. Следовательно, у мужчин значимое пополнение крови депонированными эритроцитами происходило в условиях большей ФН, по сравнению с женщинами. В последующих фазах исследования уровень гематокрита у спортсменов оставался практически неизменным (табл. 1).

Таблица 1.

Динамика параметров крови у спортсменов при проведении теста «до отказа»

\begin{tabular}{|c|c|c|c|c|c|}
\hline Показатели & $\begin{array}{c}\text { Покой, } \\
\text { сидя }\end{array}$ & До ПАНО & ПАНО & $\begin{array}{l}\text { Максималь- } \\
\text { ная нагрузка }\end{array}$ & $\begin{array}{l}\text { Восстанов- } \\
\text { ление, } 5 \text { мин }\end{array}$ \\
\hline \multicolumn{6}{|c|}{ Мужчины (n) } \\
\hline Гематокрит, \% & $\begin{array}{c}(14) \\
45,93 \pm 0,90\end{array}$ & (19) $47,74 \pm 0,51$ & $\begin{array}{c}\text { (15) } 49,31 \pm 0,51 \\
* *\end{array}$ & (19) $49,88 \pm 0,67$ & $\begin{array}{c}(18) \\
48,37 \pm 0,77 *\end{array}$ \\
\hline $\begin{array}{c}\text { Лактат } \\
\text { ммоль \л }\end{array}$ & $1,99 \pm 0,13$ & $6,38 \pm 0,36^{* * *}$ & $7,24 \pm 0,46 * * *$ & $9,72 \pm 0,54 * * *$ & $9,77 \pm 0,60 * * *$ \\
\hline Нагрузка, Вт & 0 & $257,1 \pm 14,9$ & $285,7 \pm 11,7$ & $337,1 \pm 12,4++$ & 0 \\
\hline \multicolumn{6}{|c|}{ Женщины (n) } \\
\hline Гематокрит, \% & $\begin{array}{c}(12) \\
38,47 \pm 0,79^{+++}\end{array}$ & $\begin{array}{c}(9) \\
43,84 \pm 0,56 * * *+++\end{array}$ & $\begin{array}{c}(13) \\
44,74 \pm 0,77 * * *+++\end{array}$ & $\begin{array}{c}(15) \\
44,73 \pm 0,58 * * *+++\end{array}$ & $\begin{array}{c}(14) \\
44,27 \pm 0,58 * * *+++\end{array}$ \\
\hline $\begin{array}{c}\text { Лактат } \\
\text { ммоль \л }\end{array}$ & $1,50 \pm 0,14+$ & $5,92 \pm 0,42 * * *$ & $7,42 \pm 0,41 * * *$ & $9,68 \pm 0,43 * * *$ & $9,70 \pm 0,40 * * *$ \\
\hline Нагрузка, Вт & 0 & $188,9 \pm 13,8$ & $212,3 \pm 11,4$ & $246,7 \pm 10,8+$ & 0 \\
\hline \multicolumn{6}{|c|}{ Мужчины и женщины } \\
\hline $\begin{array}{c}\text { Ретикулоци- } \\
\text { ты, \%о }\end{array}$ & $12,72 \pm 0,57$ & $11,98 \pm 0,74$ & $11,07 \pm 0,86$ & $11,92 \pm 0,73$ & $12,97 \pm 1,52$ \\
\hline $\begin{array}{c}\text { Эритроциты } \\
\text { полихромные, } \\
\%\end{array}$ & $4,09 \pm 1,18$ & $3,74 \pm 0,68$ & $5,21 \pm 1,23$ & $6,20 \pm 1,03$ & $6,88 \pm 2,69$ \\
\hline
\end{tabular}

Примечания: Статистически значимо по периодам исследования у женщин и мужчин по сравнению с покоем сидя: * $-\mathrm{p}<0,05 ; * *-\mathrm{p}<0,01 ; * * *-\mathrm{p}<0,001$ по стадиям исследования между мужчинами и женщинами: ${ }^{+++}-\mathrm{p}<0,001 ;$ между ПАНО и максимальной нагрузкой: ${ }^{\circ}-\mathrm{p}<0,01 ;{ }^{\circ 00}-\mathrm{p}<0,001$. 
Свидетельством поступления депонированных эритроцитов в циркуляцию крови можно считать проявление тенденции к уменьшению количества ретикулоцитов с 12,7 до 11,1\% в условиях ФН. В то же время увеличение относительного количества полихроматофильных эритроцитов вследствие внутриклеточной реакции клеток на микроокружение, возможно, связано с уровнем лактата ( $<0,05)$ (табл. 2$)$, повышение которого, как известно, сопровождается в крови некомпенсированным ацидозом $[16,17]$.

Уровень лактата в плазме крови во время выполнения теста «до отказа» статистически значимо повышался до максимума $(\mathrm{p}<0,001)$ и сохранялся в период восстановления, что является общей закономерностью при $Ф Н$. Показано, что в течение «утомительной» ФН у спортсменов количество молочной кислоты увеличивалось не только в плазме (капиллярная кровь), но и в эритроцитах до 15,9 ммоль/л и 4,8 ммоль/л соответственно [18]. Повышение молочной кислоты в эритроците у спортсменов высокого класса рассматривается в связи с эластичностью мембраны эритроцита, влияющей на реологические свойства крови [19].

Что касается величины эритроцитов, то по нашим данным средний диаметр эритроцитов спортсменов-лыжников после двухдневного от-

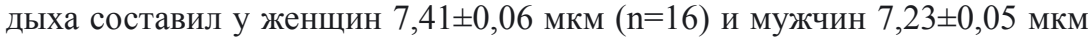
$(\mathrm{n}=12)(\mathrm{p}<0,05)$. Отмеченные половые различия соответствуют результатам исследования диаметра эритроцитов у лиц не занимающихся спортом [20]. Считается, что в «норме» средний размер эритроцитов достаточно стабилен [21], при этом поддержание величины эритроцитов определяется степенью изменчивости эритроцитов [22]. В венозной крови коэффициент вариации клеток выше, поскольку статистически значимо больше стоматоцитов, по сравнению с артериальной кровью [23]. Эритроциты в сосудах одного ранга, например, сонной и бедренной артериях имеют разный диаметр [24, 25]. В состоянии относительного покоя средний диаметр эритроцитов в циркулирующей венозной крови взрослого человека периодически меняется как форма оптимизации функции [26].

В течение ФН отмечали разнонаправленный характер изменения диаметра эритроцитов в крови, что послужило основанием для определения трех групп исследуемых спортсменов (табл. 2).

В первой группе спортсменов диаметр эритроцитов составил 7,46 $\pm 0,06$ мкм и достоверно увеличился $(\mathrm{p}<0,05)$ во время достижения ПАНО. Периоды максимальной ФН и восстановления сопровождались тенденцией к уменьшению среднего диаметра эритроцитов на 0,1 мкм (табл. 2, Рис. (А)). Для второй группы спортсменов характерно относительное 
постоянство размера эритроцитов в течение всего периода исследования. В третьей группе лиц при достижении ПАНО диаметр эритроцитов

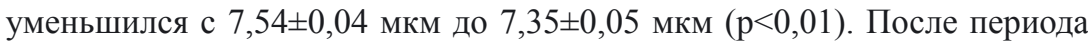

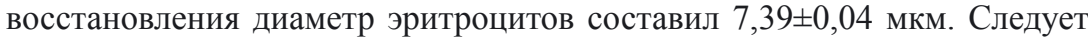
отметить, что более значимые изменения диаметра эритроцитов у спортсменов в ходе ФН характерны для нормоцитов (табл. 2, Рис. ( Б)).

Таблицуа 2.

Изменение диаметра эритроцитов в течение физической нагрузки у спортсменов-лыжников

\begin{tabular}{|c|c|c|c|c|c|c|}
\hline \multicolumn{2}{|c|}{$\begin{array}{c}\text { Группы } \\
\text { (количество } \\
\text { лиц) }\end{array}$} & $\begin{array}{c}\text { Покой, } \\
\text { сидя }\end{array}$ & До ПАНО & ПАНО & $\begin{array}{c}\text { Макси- } \\
\text { мальная } \\
\text { нагрузка }\end{array}$ & $\begin{array}{c}\text { Восстанов- } \\
\text { ление, } \\
5 \text { мин }\end{array}$ \\
\hline \multirow{2}{*}{1 (12) } & А & $7,46 \pm 0,06$ & $7,49 \pm 0,07$ & $7,68 \pm 0,08^{*}$ & $7,64 \pm 0,05$ & $7,58 \pm 0,07$ \\
\cline { 2 - 7 } & Б & $7,37 \pm 0,024$ & $7,43 \pm 0,019$ & $\begin{array}{c}7,48 \pm 0,016 \\
* * \text { о }\end{array}$ & $7,42 \pm 0,015^{*}$ & $7,40 \pm 0,014 \times$ \\
\hline \multirow{2}{*}{$2(4)$} & $\mathrm{A}$ & $7,45 \pm 0,04$ & $7,45 \pm 0,04$ & $7,43 \pm 0,05$ & $7,47 \pm 0,06$ & $7,48 \pm 0,06$ \\
\cline { 2 - 7 } & Б & $7,42 \pm 0,02$ & $7,44 \pm 0,05$ & $7,41 \pm 0,02$ & $7,41 \pm 0,03$ & $7,39 \pm 0,02$ \\
\hline \multirow{2}{*}{$3(17)$} & А & $7,54 \pm 0,040$ & $7,50 \pm 0,06$ & $7,35 \pm 0,05 * 0$ & $7,38 \pm 0,03 *$ & $7,39 \pm 0,04 *$ \\
\cline { 2 - 7 } & Б & $7,45 \pm 0,018$ & $7,42 \pm 0,022$ & $7,37 \pm 0,018^{* *}$ & $7,41 \pm 0,016$ & $7,41 \pm 0,023$ \\
\hline \multirow{2}{*}{ Итого: (33) } & А & $7,51 \pm 0,03$ & $7,48 \pm 0,03$ & $7,47 \pm 0,04$ & $7,48 \pm 0,03$ & $7,48 \pm 0,03$ \\
\cline { 2 - 7 } & Б & $7,40 \pm 0,016$ & $7,42 \pm 0,022$ & $7,37 \pm 0,018$ & $7,41 \pm 0,016$ & $7,41 \pm 0,023$ \\
\hline
\end{tabular}

Примечания. Статистически значимо по отношению к покою сидя * $-\mathrm{p}<0,05$; до ПАНО $-{ }^{\circ} \mathrm{p}<0,05$, к ПАНО $-{ }^{\mathrm{x}} \mathrm{p}<0,05$. А - диаметр эритроцитов, Б - диаметр нормоцитов.

Механизм поддержания в крови популяции эритроцитов, функционально соответствующих ФН и условиям изменения обеспечения организма кислородом, связан, вероятно, с избирательным разрушением их неустойчивых форм, который реализуется на уровне стресс-реакции в фазу мобилизации [27]. Показано, что у людей в «норме» $0,5 \%$ эритроцитов находятся в состоянии гемолиза [28]. Стресс сопровождается кратковременным увеличением активных форм кислорода и перекисным окислением липидов в биослое мембран эритроцитов [29], гиперполяризацией мембран [30,31], способствующей проницаемости ионов $\mathrm{Na}+$ [32], повышением входа Са++ и выходом К+ из клеток как большого, так и значительно меньшего размера по сравнению с нормоцитами $[33,34]$.

Поступление $\mathrm{Na}+$ в клетку вследствие активизации трансмембранного обмена $\mathrm{Na}+/ \mathrm{H}+$ [35] связано с повышением осмотического давления 
в эритроцитах, что приводит к их набуханию и, вероятно, разрушению клеточных структур. Возможно, у спортсменов-бегунов на средние дистанции аналогичный процесс избирательного разрушения неустойчивых форм клеток проявляется в сокращении времени гемолиза эритроцитов [36]. В условиях дальнейшей нагрузки эритроциты, насыщенные водой, имеют тенденцию быть более стойкими к гипо- и гипергидратации плазмы [37].

Предполагается, что гемолиз эритроцитов у 36\% исследуемых спортсменов (первая группа), вероятно, касался клеток наименьшего диаметра (микроцитов); у 12\% - (вторая группа), затрагивал равномерное разрушение клеток по всему спектру (диапазону), тогда как у 52\% - (третья группа) преобладал среди эритроцитов наибольшего диаметра (макроцитов). В этих экстремальных условиях варьирование в крови эритроцитов с разной способностью к «набуханию» является, вероятно, одним из механизмов направленных на поддержание гомеостаза и нормализацию газотранспортной функции крови, поскольку этот процесс затрагивает кислородозависимый транспорт ионов в эритроцитах $[38,39]$. Исследованиями А.М. Замковой в лаборатории Гинецинского (цит. по: Иржак, 1975) [40, с. 150] показано, что в процессе «набухания» эритроцита возрастает сродство гемоглобина к кислороду. С развитием метаболического ацидоза в эритроцитах циркулирующей крови увеличивается содержание 2,3-ДФГ, что повышает отдачу кислорода в ткани $[41,42,7]$.

Следовательно, разнонаправленность в характере изменения среднего диаметра эритроцитов у спортсменов трех групп к моменту ПАНО не зависел от исходной величины среднего диаметра, уровней гематокрита и лактата. Это может свидетельствовать о наличии различных вариантов реакции эритроцитов периферического звена эритрона в связи с внутриклеточными процессами, которые направлены на оптимизацию транспортной функции и поддержания «гомеостазиса» крови в меняющихся условиях микроокружения.

Примечательно, что увеличение физической нагрузки после достижения ПАНО не привело к дальнейшему направленному изменению среднего диаметра эритроцитов. В течение $0,25-0,5$ мин на максимальном уровне ФН «до отказа» у женщин $246,7 \pm 10,8$ Вт и у мужчин $337,1 \pm 12,4$ Вт проявился тренд к возвращению диаметра клеток к исходной величине до начала ФН. В восстановительный период средний диаметр нормоцитов, как основной субпопуляции эритроцитов, «приходит» в соответствие со средним его значением в фазу покоя (табл. 2; рис. (Б)). 


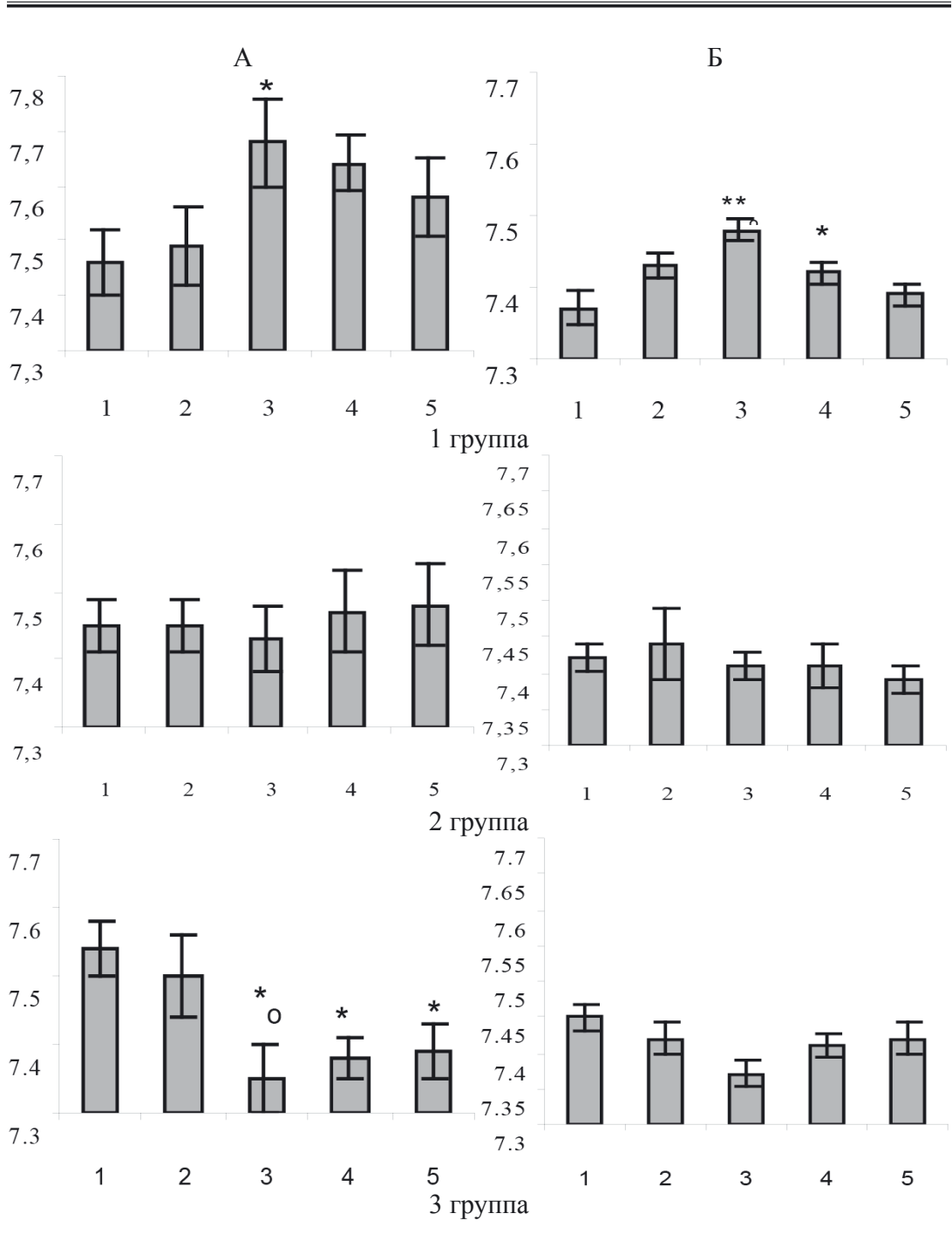

Рис. 1. Изменение диаметра эритроцитов в циркулирующей крови спортсменов ходе исследования: А - популяция эритроцитов, Б - субпопуляция нормоцитов.

По вертикали диаметр эритроцитов, по горизонтали периоды исследования

1 - покой сидя; 2 - до ПАНО; 3 - ПАНО; 4 - максимальная нагрузка;

5 - восстановление. Статистически значимо по отношению к покою сидя

${ }^{*}-\mathrm{p}<0,05,{ }^{*} *-\mathrm{p}<0,01 ;$ началу нагрузки ${ }^{\circ}-\mathrm{p}<0,05$ и ПАНО ${ }^{\mathbf{\Delta}}-\mathrm{p}<0,05$ 
В течение исследования у спортсменов суммарно не произошло значимых изменений среднего диаметра эритроцитов (табл. 2, рис. 1). Однако анализ кривой Прайс-Джонса показал, что при достижении ПАНО кривая распределения эритроцитов по диаметру в крови изменяется по-разному. В первой группе спортсменов с увеличением среднего диаметра к моменту ПАНО (табл. 2) относительное количество эритроцитов диаметром 7,2-7,5 мкм (самая многочисленная часть клеток) по отношению к исходному значению уменьшилось $(\mathrm{p}<0,001)$, в основном, за счет увеличения количества макроцитов ( $<<0,01)$, что свидетельствует о повышении гетерогенности эритроцитарной популяции (табл. 3).

Таблициа 3.

Распределение диаметра эритроцитов в крови спортсменов трех групп в момент порога анаэробного обмена

\begin{tabular}{|c|c|c|c|c|}
\hline Показатели & Покой сидя & \multicolumn{3}{|c|}{ ПАНО } \\
\hline Диаметр, мкм & Всего (33) & 1 группа (12) & 2 группа (4) & 3 группа (17) \\
\hline $6,0-6,3$ & $0,63 \pm 0,18$ & $0,41 \pm 0,19$ & 0 & $0,59 \pm 0,36$ \\
\hline $6,4-6,7$ & $3,19 \pm 0,49$ & $2,60 \pm 0,77$ & $3,00 \pm 0,41$ & $6,71 \pm 0,72 * * *$ \\
\hline $6,8-7,1$ & $6,58 \pm 0,56$ & $4,10 \pm 0,83 *$ & $6,50 \pm 1,15$ & $9,65 \pm 0,66 * * *$ \\
\hline $7,2-7,5$ & $17,53 \pm 0,66$ & $14,67 \pm 0,32 * * *$ & $15,00 \pm 1,96$ & $18,12 \pm 0,70$ \\
\hline $7,6-7,9$ & $11,52 \pm 0,69$ & $10,67 \pm 0,58$ & $12,50 \pm 1,44$ & $8,97 \pm 0,63 * *$ \\
\hline $8,0-8,3$ & $8,69 \pm 0,60$ & $12,83 \pm 1,42 * *$ & $11,00 \pm 1,08$ & $4,94 \pm 0,56 * * *$ \\
\hline $8,4-8,7$ & $1,52 \pm 0,25$ & $3,42 \pm 0,66 * *$ & $1,00 \pm 0,41$ & $0,82 \pm 0,21 *$ \\
\hline $8,8-9,1$ & $0,36 \pm 0,12$ & $1,37 \pm 0,89$ & $1,00 \pm 0,41$ & $0,18 \pm 0,13$ \\
\hline
\end{tabular}

Примечания: в скобках - количество спортсменов; статистически значимо по отношению к периоду покоя * $-\mathrm{p}<0,05, * *-\mathrm{p}<0,01, * * *-\mathrm{p}<0,001$.

Кривая Прайс-Джонса из одновершинного распределения эритроцитов (период покоя) переходит в двухвершинную форму на пороге анаэробного обмена. Известно, что двухвершинная форма распределения квазистационарная [43] и соответствует типичной гистограмме с биноминальным распределением эритроцитов [44]. Вероятно, асимметричное распределение эритроцитов может свидетельствовать о кратковременном несоответствии поступления эритроцитов в кровь или выведением их из циркуляции в условиях стресс-реакции, что показано на основании популяционно-статистической модели [45].

Во второй группе спортсменов при неизменной величине среднего диаметра эритроцитов в течение исследования (табл. 2, табл. 3 , рис. 1) 
не обнаружено статистически значимых изменений во время ПАНО по сравнению с периодом покоя, несмотря на близкое по отношению к первой группе распределение клеток в кривой Прайс-Джонса.

Напротив, одновершинное распределение диаметра эритроцитов в условиях ПАНО характерно для третьей группы спортсменов с уменьшающимся средним диаметром эритроцитов к моменту ПАНО (табл. 2, табл. 3 , рис. 1). В этой группе относительное количество эритроцитов диаметром 7,2-7,5 мкм по сравнению с первой группой не изменилось.

Следовательно, у лыжников-гонщиков при мобилизационном стрессе в условиях физической нагрузки включается механизм избирательного разрушения эритроцитов с кратковременной дестабилизацией их среднего диаметра. Направление изменения величины эритроцитов у спортсменов-лыжников в момент ПАНО не зависит от исходного диаметра эритроцитов в состоянии покоя. Индивидуально у спортсменов со средним диаметром эритроцитов, соответствующих верхней границе нормы, к моменту ПАНО наблюдали сдвиг в области макроцитов и, напротив, у спортсменов со средним диаметром эритроцитов около нижней границы нормы происходило понижение диаметра в области микроцитов.

Характер распределения эритроцитов (первая и вторая группы спортсменов) в момент ПАНО, вследствие избирательного гемолиза эритроцитов в крови, до некоторой степени свидетельствует о преимущественном включении в циркуляцию крупных эритроцитов в отличие от спортсменов третьей группы. Считается, что у спортсменов высокой квалификации в покое средний диаметр эритроцитов увеличен за счет макроцитов [46]. Возможно, что крупные клетки способны быстрее оксигенироваться в легких и отдавать кислород в тканях, поскольку увеличена площадь контакта между эритроцитом и стенкой капилляра [6] или характеризуются иным внутриклеточным метаболизмом. Этому не противоречат результаты исследования Л.Н. Катюхина [47] установившего, что в мелких сосудах происходит перемещение жидкой фазы по градиенту давления из эритроцита в просвет капилляра и, как следствие, снижение гематокрита и вязкости крови.

Следовательно, в условиях физической нагрузки в момент ПАНО формирование средней величины (диаметра) эритроцитов, вероятно, направлено, на поддержание устойчивого состояния структуры крови в связи с переходом на новый уровень энергозатрат. Поддержание средней величины эритроцитов в процессе физической нагрузки, вероятно, совпадает с внутриклеточными процессами, которые направлены на обеспечение оптимальной кислородотранспортной функции крови (оксигенации и дезокси- 
генации). Малая выборка исследуемых показателей не позволяет говорить о более эффективном выполнении физической нагрузки спортсменов-лыжников с повышающимся средним диаметром эритроцитов в периферической крови. Выяснение механизмов, лежащих в основе перераспределения эритроцитов разного диаметра в системе гемоциркуляции, является предметом самостоятельного исследования.

\section{Выводы}

У лыжников-гонщиков юношей и мужчин, девушек и женщин в возрасте 17-37 лет в состоянии ПАНО на велоэргометре определены три варианта реакции эритроцитов, соответствующих их средней величине: увеличение диаметра эритроцитов у $36 \%$ спортсменов, уменьшение $52 \%$ и без изменений $-12 \%$.

В течение 0,25-0,5 мин на максимальном уровне физической нагрузки «до отказа» и в течение 5-и мин восстановления у спортсменов с квалификацией КМС и МС проявился тренд к возвращению диаметра клеток к исходному значению.

Лыжники-гонщики независимо от половой принадлежности с повышающимся средним диаметром эритроцитов в крови к моменту ПАНО характеризовались двухвершинной формой кривой Прайс-Джонса, с понижающимся средним диаметром или без изменений - одновершинной.

Динамика статистически значимого изменения размера эритроцитов в большей степени характерна для центрального звена периферического эритрона - нормоцитов. Предполагается, что различная реакция эритроцитов у спортсменов с повышенными и пониженными величинами среднего размера клеток проявляется в избирательной элиминации преимущественно крайних вариантов микро- и макроцитов.

\section{Список литературы}

1. Карчинская Т.В. Лабораторная гемоцитология: методы исследования и клинико-диагностическое значение изучения эритроцитов. Методические рекомендации. Ставрополь: Изд-во СевКавГТУ, 2007. 62 с.

2. Хныченко Л.К., Сапронов Н.С. Стресс и его роль в развитии патологических процессов // Обзоры по клинической фармакологии и лекарственной терапии. 2003. Т. 2. С. 2-15.

3. Peripheral Circulation / Laughlin M.N., Davis M.J., Secher N.H., van Lichayt J.J., Apce-Eskiwelj A.A., Simmons G.H., Bender S.B., Padilla J., Bache R.J., Merkus D., Duncker D.J. // Compr. Physiol. 2012. Vol. 2, Issue 1, pp. 321-447. 
4. Адсорбция углеводов и липидов эритроцитами при недозированной физической нагрузке / Макарушко С.Г., Мурзамадиева А.А., Смагулова 3.Ш., Садыкова Х.М. // Рос. физиол. журн. им. И.М. Сеченова. 2004. Т.90. № 8. C. $140-141$.

5. Minetti M., Malorni W. Redox control of red blood cell biology the red blood cell as a target and source of prooxidant species // Antioxid Redox Signal. 2006. Vol. 8. № 7-8, pp. 1165-1169.

6. Иванов К.П. Основы энергетики организма. Т. 2. Биологическое окисление и его обеспечение кислородом. СПб: Наука, 1993. 270 с.

7. Луценко М.М. Газотранспортный обмен в периферической крови при общем охлаждении организма // Бюллетень физиологии и патологии дыхания. 2012. Вып. 44. С. 85-89.

8. Патология мембран форменных элементов крови при заболеваниях и в эксперименте / Бархина Т.Г., Никитина Г.М., Бархина М.М., Черных Ф.С. // Успехи современного естествознания. 2006. № 6. С. 64-65.

9. Александров Н.П. Изменения в системе красной крови человека (эритроне) при адаптации к новым условиям // Земский Врач. 2010. № 1. С. 23-27.

10. Cicha I., Suzuki Y., Tateishi N., Maeda N. Changes of RBC aggregation in oxygenation-deoxygenation: $\mathrm{pH}$ dependency and cell morphology // Am. J. Physiol. Heart Circ. Physiol. 2003. Vol. 284, № 6, pp. 2335-2342.

11. Тодоров Й. Клинические лабораторные исследования в педиатрии. София: Медицина, 1968. 1065 с.

12. Лабораторные методы исследования в клинике: Справочник / Под ред. В.В. Меньшикова. М.: Медицина, 1987. 358 с.

13. Аршинова Н.Г. Сопряженность основных гематологических параметров и показателей ЭХОКС у спортсменов в состоянии относительного покоя // Молодой ученый. 2010. № 10. С. 319-323.

14. Колупаев В.А., Сашенков С.Л. Динамика показателей периферического отдела эритрона у спортсменов в различные сезоны года под влиянием анаэробных или аэробных физических нагрузок // Вестник ЮУрГУ. 2007. № 16. С. 134-136.

15. Мчедвишвили Г.И., Варазашвили М.Н. Различия в концентрации эритроцитов и величине гематокрита в крови в зависимости от локализации сосудов и интенсивности кровотока // Бюл. эксп. биол. и мед. 1986. Т. 102. № 10. С. 387-388.

16. Петрушова О.П., Микуляк Н.И. Кислотно-основное равновесие крови спортсменов при физической нагрузке // Биомедицинская химия. 2014. Т. 60. № 5. C. 591-595. 
17. Дроздов Д.Н., Кравцов А.В. Влияние физической нагрузки на показатели периферической крови человека // Журн. Веснік Мазырскага дзяржаунага педагагічнага універсітэта імя I. П.Шамякіна. 2015. № 1 (45). C. 23-28.

18. Lactate concentration in plasma and red blood cells during incremental exercise / Hildebrand A., Lormes W., Emmert J., Liu Y., Lehmann M., Steinacker J.M. // Int. J. Sports Med. 2000. Vol. 21. № 7, pp. 463-468.

19. Maximal exercise and lactate do not change red blood cell aggregation in well trained athletes / Connes P., Caillaud C., Py G., Mercier J., Hue O., Brun J.F. // Clinical Hemorheology and Microcirculation. 2007. Vol. 36. № 4, pp. 319-326.

20. Тукин В.Н., Федорова М.3. Геометрический профиль и агрегационная способность эритроцитов здоровых мужчин и женщин // Успехи современного естествознания. 2011. № 6. С. 29-30.

21. К вопросу о соотношении количества эритроцитов и их размеров в периферической крови / Козинец Г.И., Шмаров Д.А., Левина Т.Н., Рябенкова О.И., Скрипка А.В., Соболевская Л.В. // Клиническая лабораторная диагностика. 2002. № 4. С. 43-45.

22. Как регулируется объем эритроцита, или что могут и чего не могут математические модели в биологии / Атауллаханов Ф.И., Корунова Н.О., Спиридонов И.С., Пивоваров И.О., Колягина Н.В., Мартынов М.В. // Биологические мембраны. 2009. Т. 26. № 3. С. 163-179.

23. Ионов Б.В., Чернух А.М. Морфологическая характеристика эритроцитов артериальной и венозной крови крысы по данным сканирующей электронной микроскопии // Бюл. эксп. биол. и мед. 1981. № 12. С. 749-752.

24. Медведев М.А., Нестерова Т.П., Голосов О.С. Морфофункциональная характеристика перераспределения эритроцитов в различных сосудистых регионах // Физиол. журн. СССР им. И.М. Сеченова. 1989. Т. 25. № 1. C. $38-42$.

25. Физиологческое распределение эритоцитов на уровне дуги аорты по данным цитометрического и спектрофлуометрического исследования / Медведев М.А., Коваль Г.С., Рязанцева Н.В., Чурбанова М.А., Юрьева В.Д. // Вестник Томского госуниверситета, 2007. № 300 (2). С. 170-171.

26. Монгалёв Н.П., Иржак Л.И. Вариабельность диаметра эритроцитов взрослого человека в условиях 80-минутного мониторинга // Вестник Сыктывкарского госуниверситета. Серия 2 (биология, геология, химия, экология). 2015. Вып. 5. С. 63-67.

27. Сотникова Е.Д. Изменения в системе крови при стрессе // Вестник РУДН. Серия: Агрономия и животноводство. 2009. № 1. С. 50-55. 
28. Кидалов В.Н., Лысак В.Ф. Квантитативная эритрограмма и возможность ее использования в клинике и эксперименте // Лабораторное дело. 1989. № 8. С. 36-40.

29. Владимиров Ю.А. Свободные радикалы и антиоксиданты // Вестн. Рос. АMH. 1998. № 7. C. 43-51.

30. Lassen U.V., Pape L., Vestergaard-Bogind B. Effect of calcium on the membrane potential of Amphiuma red cells // J. Membr. Biol. 1976. V. 26, N 1, pp. 51-70.

31. Bickler P.E., Buck L.T. Hypoxia Tolerance in Reptiles, Amphibians, and Fishes: Life with Variable Oxygen Availability // Annu. Rev. Physiol. 2007. V. 69, N 2, pp. 145-170.

32. Губанов Н.И., Утепбергенов А.А. Медицинская биофизика. М.: Медицина, 1978. 335 с.

33. Гольдберг Д.И. Левина Г.Д. Диаметр эритроцитов в норме и патологии. Томск, 1969. $115 \mathrm{c}$.

34. Berridge M.J., Bootman M.D., Lipp Pl. Calcium - a life and death signal // Nature. 1998. Vol. 395, № 6703, pp. 645-648.

35. Perry S.F., Thomas S. The effects of endogenous of exogenous catecholamines on blood respiratory status during acute hypoxia in rainbow trout // J. Comp. Physiol. 1991. V. 161, pp. 489-497.

36. Изменение кислотной резистентности эритроцитов периферической крови спортсменов, занимающиеся бегом на средние дистанции / Дычко Е.А., Казимирко Н.К., Дычко В.В., Кохан С.Т., Гаврилин В.А. // Спортивная медицина: Наука и практика. 2014. № 1. С. 16-21.

37. Functional significance of cell volume regulatory mechanisms / Lang F., Busch G.L., Ritter M., Völkl H., Waldegger S., Gulbins E. , Haussinger D. // Physiol Rev., 1998. V. 78, pp. 247-306.

38. Иржак Л.И. Действие растворов солей и глюкозы на сродство гемоглобина к кислороду у крыс // Физиол. журн. СССР. 1988. Т. 74. № 4. С. $564-$ 568.

39. Показатели гликемии при выраженной экзогенной острой нормобарической гипоксии у человека в покое / Бойко Е.Р., Бурых Э.А., Потолицина Н.Н., Людинина А.Ю., Вахнина Н.А., Шадрина В.Д., Паршукова О.И., Иржак Л.И., Сороко С.И. // Физиол. чел. 2010. Т. 36, № 3. С. 110-116.

40. Иржак Л.И. Гемоглобины и их свойства. М.: Наука. 1975. 240 с.

41. Гладилов В.В. Влияние гипоксии и гипероксии на показатели красной крови и кислородосвязующие свойства гемоглобина млекопитающих до и после рождения // Автореф. дис. ... докт. биол. наук: 03.00.13. Москва, 1992. $43 \mathrm{c}$. 
42. Ivanova S.M., Brazhe N.A., Luneva O.G., Yarlikova Y.V., Labetskaya O.I., Parshina E.Y., Baizhumanov A.A., Maksimov G.V., Morukov B.V. Physical-chemical properties of plasma membrane and function of erythrocytes of cosmonauts after long-term space flight // Acta Astronautica. 2011. Vol. 68, № 9-10, pp. 15171522.

43. Молчанов А.М. Возможная роль колебательных процессов в эволюции // Колебательные процессы в биохимических и химических системах: Тр. Всес. симпоз. М.: Наука, 1967. С. 274-288.

44. Скверчинская Е.А., Никитина Е.П. Эритроциты мышей при алиментарном голодании и восстановительном питании (проточная цитометрия) // XXII съезд Физиологического общества им. И.П.Павлова: Тез. докл. Волгоград: Изд-во ВОЛГГМУ, 2013. С. 483.

45. Балаховский И.С. Популяционно-статистическая методология выявления механизмов физиологической регуляции концентрации в крови некоторых биохимических веществ // Физиология человека. 2009. Т. 35. № 3. С. 94-100.

46. Викулов А.Д., Маргазин В.А., Бойков В.Л. Диаметр эритроцитов как надежный маркер текущего функционального состояния организма и физической работоспособности спортсменов // Лечебная физкультура и спортивная медицина. 2015. № 1. С. 10-14.

47. Катюхин Л.Н. К объяснению механизма влияния сдвигового напряжения на вязкостные параметры крови в сосудах малого диаметра // Science Rise. 2014. T. 5, № 4 (5) C. 24-29.

\section{References}

1. Karchinskaya T.V. Laboratornaya gemotsitologiya: metody issledovaniya $i$ kliniko-diagnosticheskoe znachenie izucheniya eritrotsitov. Metodicheskie rekomendatsii [Laboratory gemocitology: research methods and clinical diagnostic value of the study of erythrocytes. Guidelines]. Stavropol', SevKavGTU, 2007. 62 p. (in Russian).

2. Khnychenko L.K., Sapronov N.S. Stress and its role in the development of pathological processes. Obzory po klinicheskoi farmakologii i lekarstvennoi terapii. [Surveys of clinical pharmacology and drug therapy]. 2003, vol. 2, no 3, pp. 2-15 (in Russian).

3. Peripheral Circulation. Laughlin M.N., Davis M.J., Secher N.H., van Lichayt J.J., Apce-Eskiwelj A.A., Simmons G.H., Bender S.B., Padilla J., Bache R.J., Merkus D., Duncker D.J. Compr. Physiol., 2012, vol. 2, no 1, pp. 321-447.

4. Makarushko S.G., Murzamadieva A.A., Smagulova Z.Sh., Sadykova Kh.M. Carbohydrates and Lipids erythrocyte adsjrbtion during undosated physical ac- 
tivity. Rossiiskiy fiziologicheskiy zhurnal im. I.M.Sechenova [Neuroscience and Behavioral Physiology - Sechenov Physiology Journal], 2004, vol. 90, no 8, pp. 140-141 (in Russian).

5. Minetti M., Malorni W. Redox control of red blood cell biology^ the red blood cell as a target and source of prooxidant species. Antioxid Redox Signal. 2006, vol. 8, is. 7-8, pp. 1165-1169.

6. Ivanov K.P. Osnovy jenergetiki organizma: Teoreticheskie i prakticheskie aspekty. T. 2: Biologicheskoe okislenie i ego obespechenie kislorodom [The basics of the body energy: theoretical and practical aspects. T. 2: Biological oxidation and oxygen supply]. St.-Petersburg, Nauka, 1993, 270 p (in Russian).

7. Lutsenko M.M. Gas-transport metabolism in the peripheral blood at general cooling of the organism. Biulleten'fiziologii i patologii dykhaniia [Bulletin Physiology and Pathology of Respiration], 2012. vol. 44, pp. 85-89 (in Russian).

8. Barkhina T.G., Nikitina G.M., Barkhina M.M., Chernykh F.S. Pathology of the membranes of blood cells in diseases, and in the experiment. Uspekhi sovremennogo estestvoznaniya. 2006, no 6, pp. 64-65 (in Russian).

9. Aleksandrov N.P. Changes in he system of the red of human blood (Eritrea) when adapting to new conditions. Zemskii Vrach. 2010, no 1, pp. 23-27 (in Russian).

10. Cicha I., Suzuki Y., Tateishi N., Maeda N. Changes of RBC aggregation in oxygenation-deoxygenation: $\mathrm{pH}$ dependency and cell morphology. Am. J. Physiol. Heart Circ. Physiol. 2003, vol. 284, no 6, pp. 2335-2342.

11. Todorov I. Klinicheskie laboratornye issledovaniia v pediatrii [Clinical laboratory studies in pediatric]. Sofiia, Meditsina, 1968. $1065 \mathrm{p}$ (in Russian).

12. Laboratornye metody issledovaniya v klinike: Spravochnik / Pod red. V.V. Men shikova. [Laboratory Methods in clinic: Reference Guide]. Moscow, Meditsina, 1987, 358 p (in Russian).

13. Arshinova N.G. The conjugation of the main hematological parameters and indicators EHOX of athletes in a state of relative calm. Molodoi uchenyi. 2010, no 10, pp. 319-323 (in Russian).

14. Kolupaev V.A., Sashenkov S.L. Dynamics of peripheral erythrone indicators of athletes in different seasons of the year under the influence of anaerobic or aerobic physical activities. Vestnik IuUrGU. 2007, no 16, pp. 134-136 (in Russian).

15. Mchedvishvili G.I., Varazashvili M.N. Differences in the concentration of erythrocytes and a hematocrit value in the blood depending on the localization of blood vessels and intensity of blood. Byulleten' eksperimental'noy biologii $i$ mediciny [Bulletin of Experimental Biology and Medicine]. 1986, vol. 102, no 10, pp. 387-388 (in Russian). 
16. Petrushova O.P., Mikuliak N.I. Biood acid-base balance of sportsmen during physical activity. Biomeditsinskaya Khimiya, 2014, vol. 60. no 5, pp. 591-595 (in Russian).

17. Drozdov D.N., Kravtsov A.V. Effect of exercise on indicators of human peripheral blood. Zhurn. Vesnik Mazyrskaga dzjarzhaunaga pedagagichnaga universitjeta imja I. P.Shamjakina. 2015, vol. 1 (45), pp. 23-28 (in Russian).

18. Hildebrand A., Lormes W., Emmert J., Liu Y., Lehmann M., Steinacker J.M. Lactate concentration in plasma and red blood cells during incremental exercise. Int J. Sports Med. 2000, vol. 21, no 7, pp. 463-468.

19. Connes P., Caillaud C., Py G., Mercier J., Hue O., Brun J.F. Maximal exercise and lactate do not change red blood cell aggregation in well trained athletes. Clinical Hemorheology fnd Microcirculation. 2007, vol. 36, no 4, pp. 319-326.

20. Tukin V.N., Fedorova M.Z. Geomeyric profiles and aggregation ability of erythrocytes to healthy men and women. Uspekhi sovremennogo estestvoznaniya. 2011, no 6, pp. 29-30 (in Russian).

21. Kozinets G.I., Shmarov D.A., Levina T.N., Riabenkova O.I., Skripka A.V., Sobolevskaia L.V. To the question of the ratio on the number of erythrocytes and their size in the peripheral blood. Klinicheskaya laboratornaya diagnostika [Russian clinical laboratory diagnostics]. 2002, no 4, pp. $43-45$ (in Russian).

22. Ataullakhanov F.I., Korunova N.O., Spiridonov I.S., Pivovarov I.O., Koliagina N.V., Martynov M.V. How Erythrocyte Volume Is Regulated, or What Mathematical Models Can and Cannot Do for Biology. Biologicheskie membrany [Membrane and Cell Biology ]. 2009, vol. 26, no 3, pp. 153-179 (in Russian).

23. Ionov B.V., Chernukh A.M. Morphological characteristics of arterial and venous rat blood's erythrocytes according to scanning electron microscopy. Byulleten'eksperimental'noy biologii i mediciny [Bulletin of Experimental Biology and Medicine]. 1981, no 12, pp. 749-3752 (in Russian).

24. Medvedev M.A., Nesterova T.P., Golosov O.S. Morphofunctional characteristic erythrocytes' redistribution in various vascular regions. Fiziologicheskii zhurnal SSSR im. I.M.Sechenova [Journal of Physiology of USSR]. 1989, vol. 25, no 1, pp. 38-42 (in Russian).

25. Medvedev M.A., Koval' G.S., Riazantseva N.V., Churbanova M.A., Iur'eva V.D. Physiological distribution of erythrocytes in aortic arch on the data cytometrical and spectrofluorimetrical researches. Vestnik Tomskogo gosuniversiteta [Tomsk State University Journal]. 2007, no 300 (2), pp. 170-171 (in Russian).

26. Mongalev N.P., Irzhak L.I. Erythrocytes diameter variability at 80-min monitoring in adult man. Vestnik Syktyvkarskogo gosuniversiteta. Seriya 2 (biologiya, geologiya, khimiya, ekologiya). 2015, vol. 5, pp. 63-67 (in Russian). 
27. Sotnikova E.D. Changes in blood system at stress. Zhurnal Vestnik Rossiiskogo universiteta druzhby narodov. Seriia: Agronomiia i zhivotnovodstvo [Bulletin of Peoples' Friendship University of Russia. Series Agronomy and Animal Industries]. 2009, vol. 1, pp. 50-55 (in Russian).

28. Kidalov V.N., Lysak V.F. Quantitative erythrograms and the possibility of its use in clinical and experimental. Laboratornoe delo. 1989, no 8, pp. 36-40 (in Russian).

29. Vladimirov Iu.A. Free radicals and antioxidants. Vestnik Rossiyskoy Akademii Meditsinskikh Nauk [Annals of Russian Academy of Medical Sciences]. 1998, no 7, pp. 43-51 (in Russian).

30. Lassen U.V., Pape L, Vestergaard-Bogind B. Effect of calcium on the membrane potential of Amphiuma red cells. J. Membr. Biol. 1976, vol. 26, no 1, pp. 51-70.

31. Bickler P.E., Buck L.T. Hypoxia Tolerance in Reptiles, Amphibians, and Fishes: Life with Variable Oxygen Availability. Annu. Rev. Physiol. 2007, vol. 69, no 2, pp. 145-170.

32. Gubanov N.I., Utepbergenov A.A. Meditsinskaia biofizika [Medical biophysics]. Moscow, Meditsina, 1978, 335 p. (in Russian).

33. Gol'dberg D.I., Levina G.D. Diametr eritrotsitov v norme i patologii [The diameter of erythrocytes in norm and pathology]. Tomsk, 1969, 115 p. (in Russian).

34. Berridge M.J., Bootman M.D., Lipp Pl. Calcium - a life and death signal. Nature. 1998, vol. 395, no 6703, pp. 645-648.

35. Perry S.F., Thomas S. The effects of endogenous of exogenous catecholamines on blood respiratory status during acute hypoxia in rainbow trout // J. Comp. Physiol. 1991, vol. 161, pp. 489-497.

36. Dychko E.A., Kazimirko N.K., Dychko V.V., Kokhan S.T., Gavrilin V.A Changes in peripheral blood erythrocytes acid resistance in medium distances runners. Sportivnaia meditsina: Nauka i praktika. 2014, no 1, pp. 16-21 (in Russian).

37. Lang F., Busch G.L., Ritter M., Völkl H., Waldegger S., Gulbins E., Haussinger D. Functional significance of cell volume regulatory mechanisms. Physiol Rev. 1998, vol. 78, pp. 247-306.

38. Irzhak L.I. The action of glucose and salt solutions on hemoglobin and oxygen affinity in the rat. Fiziologicheskiy zhurnal SSSR [Journal of Physiology of USSR]. 1988, vol. 74, no 4, pp. 564-568 (in Russian).

39. Boiko E.R., Burykh E.A., Potolitsina N.N., Liudinina A.Iu., Vakhnina N.A., Shadrina V.D., Parshukova O.I., Irzhak L.I., Soroko S.I. Serum glucose Level in Acute Severe Hypoxia in Human at Rest. Fiziologiya cheloveka [Human Physiology]. 2010, vol. 36, no 3, pp. 110-116 (in Russian). 
40. Irzhak L.I. Gemoglobiny i ikh svoistva [The Hemoglobins and their properties]. Moscow, Nauka, 1975, 240 p. (in Russian).

41. Gladilov V.V. The Effect of hypoxia and hyperoxia on the red blood counts and hemoglobin properties of mammals before and after the birth. Extended abstract of Doctor's thesis. Moscow, 1992, 43 p. (in Russian).

42. Ivanova S.M., Brazhe N.A., Luneva O.G., Yarlikova Y.V., Labetskaya O.I., Parshina E.Y., Baizhumanov A.A., Maksimov G.V., Morukov B.V. Physical-chemical properties of plasma membrane and function of erythrocytes of cosmonauts after long-term space flight. Acta Astronautica. 2011, vol. 68, no 9-10, pp. 1517-1522.

43. Molchanov A.M. Possible role of oscillating processes in evolution. Kolebatel'nye protsessy $v$ biokhimicheskikh $i$ khimicheskikh sistemakh. Trudy Vsesoyuznogo simpoziuma [Oscillatory processes in biochemical and chemical systems. Proc. of the All-Union Symposium]. Moscow, Nauka, 1967, pp. 274 288 (in Russian).

44. Skverchinskaia E.A., Nikitina E.P. Mice erythrocytes at alimentarystarvation and recovery nutrition (flow cytometry). XXII s"ezd Fiziologicheskogo obshchestva im. I.P.Pavlova: Tez. dokl. [XXII Congress of the Pavlov Physiological Society: Abstracts of Papers]. Volgograd: Izdatel'stvo VolgGMU, 2013, p. 483 (in Russian).

45. Balakhovskii I.S. Population statistical methodology for determining the mechanisms of physiological regulation of concentrations of some biochemical substances in blood. Fiziologiya cheloveka [Human Physiology]. 2009, vol. 35, no 3, pp. 94-100 (in Russian).

46. Vikulov A.D., Margazin V.A., Boikov V.L. Erythrocyte diameter as a reliable marker of current functional stste of organism and physical performance of athletes. Lechebnaia fizkul 'tura i sportivnaia meditsina. 2015, no 1, pp. 10-14 (in Russian).

47. Katiukhin L.N. To explain the mechanism of shear stress effect on the viscosity parameters of blood in e vessels of small diameter. Science Rise. 2014, vol. 5, no 4 (5), pp. 24-29 (in Russian).

\section{ДАННЫЕ ОБ АВТОРАХ}

Рубцова Лидия Юрьевна, младший научный сотрудник Отдела экологической и медицинской физиологии Федеральное государственное бюджетное учреждение науки Институт физиологии Коми научного иееттра Уральского отделения Российской академии наук 
ул. Первомайская, 50, г. Сыктылккар, ГСП-2, 167982, Республика Коми, Российская Федерачия

lidiyarubcova@mail.ru

Потолицына Наталья Николаевна, к.б.н., руководитель группы метаболизма человека Отдела экологической и медицинской физиологии

Федеральное государственное бюджетное учреждение науки Институт физиологии Коми научного иентра Уральского отделения Российской академии наук

ул. Первомайская, 50, г. Сыктывккар, ГСП-2, 167982, Республика Коми, Российская Федерачия potol_nata@list.ru

Монгалёв Николай Петрович, к.б.н., старший научный сотрудник Отдела экологической и медицинской физиологии Федеральное государственное бюджетное учреждение науки Институт физиологии Коми научного иеентра Уральского отделения Российской академии наук ул. Первомайская, 50, г. Сыктылвкар, ГСП-2, 167982, Республика Коми, Российская Федерачия mongalev@physiol.komisc.ru

\section{DATA ABOUT THE AUTHORS}

Rubtsova Lidiya Yurevna, Research Assistant, Department of Environmental and Medical Physiology

Institute of Physiology, Komi Science Centre, Urals Branch of Russian Academy of Science, Syktyvkar, Russia

50, Pervomaysksya Str., Syktyvkar, 167982, Russian Federation

lidiyarubcova@mail.ru

SPIN-code: 3083-6642

ORCID: 0000-0003-3262-7337

ResearcherID: C-6803-2017

Potolitsyna Natalya Nikolaevna, Cand. of Biol. Sc., Senior Researcher, Department of Environmental and Medical Physiology Institute of Physiology, Komi Science Centre, Urals Branch of Russian Academy of Science, Syktyvkar, Russia 
50, Pervomaysksya Str., Syktyvkar, 167982, Russian Federation potol_nata@list.ru

Mongalev Nikolay Petrovich, Cand. of Biol. Sc., Senior Researcher, Department of Environmental and Medical Physiology

Institute of Physiology, Komi Science Centre, Urals Branch of Russian Academy of Science, Syktyvkar, Russia 50, Pervomaysksya Str., Syktyvkar, 167982, Russian Federation mongalev@physiol.komisc.ru

SPIN-code: 6768-5599

ORCID: 0000-0002-2817-5780

ResearcherID: P-9671-2016 